\author{
Janina MolcZanow*, Richard Wiese** \\ ${ }^{*}$ Uniwersytet Warszawski \\ Instytut Lingwistyki Stosowanej \\ ** Philipps-Universität Marburg \\ Institut für Germanistische Sprachwissenschaft
}

\title{
Rhythm is in the mind of the beholder Remarks on the nature of linguistic rhythm
}

Key w ord s: phonetics; phonology; prosodic structure; rhythm

Słow a klucze: fonetyka; fonologia; struktura prozodyczna; rytm

\section{Introduction}

Rhythm (from Greek $\dot{\rho} v \theta \mu o ́ s$ - rhythmos, "any regular recurring motion, symmetry") characterizes most types of human activity which develop in time ${ }^{1}$. Rhythmicity is observed in automatic activities such as breathing, heartbeat, sleep, but the tendency to structure temporal events is also seen in controlled, cognitive activities such as dance, music and speech. Beats in music, taps in dance and syllables in speech are used, inter alia, to divide time into isochronous passages. St. Augustine observed many centuries ago that "in omnibus rerum motibus quid numeri valeant, facilius consideratur in vo-

${ }^{1}$ We are grateful to four anonymous reviewers of Linguistica Copernicana for their valuable comments. 
cibus" "the role that meter plays in all movements, is seen more readily in speech" 2 . Yet, up to the present day, rhythm remains one of the most understudied areas in linguistics.

The aim of the present article is to provide a review and a critical assessment of current approaches to linguistic rhythm. It is argued that phonetically-based models which treat rhythm as an emergent property are insufficient to account for cross-linguistic variation and that the intuitive notion of rhythm should be explicitly modelled by drawing upon the concepts of a phonological theory.

\section{The search for phonetic correlates}

Some kind of rhythmic structure is detectable in most, if not all, languages. At the perceptual level, acoustically salient events form a regular timing pattern. Languages are usually considered to fall into two rhythmic groups, metaphorically called 'machine-gun rhythm' and 'Morse code rhythm' (Lloyd James 1940). In the first half of the 20th century, Pike (1945) introduced the terms syllable-timed rhythm and stress-timed rhythm to refer to these two types of rhythmic structures, respectively. In the former, syllables were perceived to be isochronous (e.g. Italian, French, Turkish), whereas in the latter, stressed syllables were considered to occur at regular intervals of time (e.g. English, German, Russian). Furthermore, smaller prosodic units moras - were reported to be equidistant in languages such as Japanese, Tamil, or Luganda. Since then, the phenomenon of isochrony at the levels of the mora, syllable or the stressed syllable (foot) has attracted a considerable amount of attention in the literature.

However, numerous phonetic studies (e.g., Bolinger 1965, Lehiste 1977, Dauer 1983, Jassem et al. 1984), failed to confirm the objective existence of isochrony. That is, it has been demonstrated that there is a considerable degree of variation in the length of syllables and feet (as carriers of stress) in syllable-timed and stress-timed languages, respectively.

Some researchers, in an attempt to account for the intuitive distinction into machine-gun $v s$. Morse code rhythmic classes, assume that different rhythms are derivative from other phonetic properties, such as syllable weight, com-

2 Cited after Liberman (1975:311). 
plexity, segmental sonority, lexical stress, occurrence of vowel reduction, etc. (Dauer 1983, Auer 1993, Ramus et al. 1999, Grabe and Low 2002, Dellwo 2010). All these studies in one way or the other subscribe to the view that "(...) the rhythmic effect is a purely automatic consequence of linguistic circumstance" (Classe 1939:132).

It also should be noted that there is a possibility that languages do not fall into distinct classes but, rather, are placed along a continuum ranging from stress-timed to syllable-timed languages (Dauer 1987). This assumption is confirmed by the existence of languages such as Polish, which cannot be placed into one of the established rhythmic categories because it displays characteristics of both stress- and syllable-timing (Ramus et al. 1999). To reconcile the rhythm class hypothesis with the possibility of rhythmic continuum, Ramus et al. (2003) suggest that there are more categories, with Polish belonging to a distinct rhythmic class ${ }^{3}$.

The predominant approach in the recent phonetic research is to quantify rhythmic differences among languages using different metrics. In an algorithm proposed by Ramus et al. (1999), rhythm is determined by the duration of vocalic intervals $\% \mathrm{~V}$ and the deviation of consonantal duration $\Delta \mathrm{C}$, which is directly correlated with syllabic complexity. Other metrics (Grabe and Low 2002) distinguish rhythmic classes using the PVI (Pairwise Variability Index) measures, which compare the variability of successive vocalic and intervocalic intervals. The PVI is calculated by summing the differences between pairs of successive intervals, and then divided by the number of pairs. These studies have shown that syllable-timed languages usually have low vocalic and consonantal PVIs, whereas stress-timed languages exhibit higher variation in the duration of vocalic and intervocalic intervals.

Measurements based on different metrics are problematic for several reasons. First, they produce contradictory results (Arvaniti 2009). For instance, Thai can be classified as either stress-timed or syllable-timed, depending on the metrics used (Grabe and Low 2002). ${ }^{4}$ Furthermore, if phonetic correlates

3 On the other hand, Malisz (2011) presents evidence that Polish is syllable-timed.

4 As pointed out by an anonymous reviewer, language-specific rhythmic patterns should be distinguished from sentence-specific patterns. For instance, a sentence in English can consist only of CV syllables, which will be similar in timing patterns to the sentence in French, or it can consist of complex syllables, exhibiting high degree of variability. 
of rhythm are to be found in the measurements of consonantal and vocalic interval durations, then the prediction is that structurally similar languages, and, especially dialects of the same language, should not differ with respect to rhythmic organization. Yet, it is not unusual for historically closely related languages to have distinct rhythmic structures. For instance, two Turkic languages, Uzbek and Turkish, belong to stress-timed and syllable-timed classes, respectively (Sjoberg 1963, Lewis 1967). Similarly, in Italian and Portuguese, a pair of two Romance languages with comparable syllable structure, the former is described as syllable-timed, whereas the latter is described as stress-timed (Major 1981, Farnetani and Kori 1990). Furthermore, distinct rhythmic types can be found in different dialects of one language. Standard Russian, for example, is a typical stress-timed language, whereas most of its northern dialects have rhythmic characteristics of syllable-timing (Kasatkin 2005: 25). Notably, the most salient feature differentiating northern Russian dialects from standard Russian is the absence of vowel reduction (Avanesov and Orlova 1965). Likewise, in the case of the Uzbek/Turkish pair mentioned, vowel reduction occurs in the first, but not in the second language. To account for the fact that stress-timing frequently co-occurs with vowel reduction, it has been assumed that greater variability of vocalic intervals, and, hence, a stress-timed rhythmic effect, are achieved due to a shorter duration of reduced vowels in comparison to unreduced vowels. In spite of its appeal, this approach is subject to a number of objections. On the empirical side, it does not accommodate the fact that both syllable-timed Italian and stressed-timed Portuguese have vowel reduction (Crosswhite 2001). This approach is also problematic on theoretical grounds. Specifically, the view that rhythm is a perceptual phenomenon based on the combination of phonetic properties, the most important of which is the variability of segmental intervals, divorces rhythm from stress. However, beginning with Sweet (1906), the rhythmic character of stress has been considered one of its most salient properties. Moreover, vowels in languages with vowel reductions typically undergo different qualitative and quantitative changes when they occur in unstressed positions. Since vocalic quality is determined by the presence or absence of stress, vowel reduction is a stress-dependent process. Therefore, assuming vowel reduction to be 'a source' of stress-timing pattern is a reversal of cause and effect, or at least implies a paradoxical situation with unclear causes and effects. 
In addition, it is not clear how this model of rhythm perception can be reconciled with the data from the first language acquisition. In this area, experimental studies reveal that newborns can already discriminate languages from different rhythmic types (Bahrick and Pickens 1988, Mehler et al. 1988, and others), whereas sensitivity to phonotactics (the putative source of rhythmic types) emerges no sooner than in the ninth month (Jusczyk et al. 1994). It is a matter of debate, then, whether infants can compute syllabic complexity to extract rhythm from the ambient language. In addition, recent studies have revealed that two-year olds produce language-specific rhythmic patterns at the time when their speech is still devoid of complex syllables and consists mainly of simple CV syllables (Payne et al. 2012, Prieto et al. 2012). This shows that phonotactic patterning cannot affect the durational ratios of consonantal and vocalic intervals.

Furthermore, if the perception of rhythm is derivative from the syllable structure and the proportion of vowels and consonants in the acoustic signal, a learner acquiring a rhythmically distinct foreign language should automatically produce the correct rhythmic pattern, if he or she can produce all the segments and their durational properties correctly. This, of course, is not true. The use of an incorrect rhythm is one of the most salient indicators of a foreign accent, and a different rhythmic pattern is one of the most difficult aspects in the acquisition of second language pronunciation (O'Connor 1980: 100).

The futile search for phonetic correlates of rhythm in the acoustic signal raises the question whether there is rhythm in the first place. Perhaps it is just a phonetic illusion, or, as Liberman (1975: 264) put it "(...) collective hallucination, or at best a tendency which influences the temporal patterning of speech in a relatively marginal way"? This view is advocated by Dasher and Bolinger (1982), who, put off by the lack of experimental evidence, deny rhythm any theoretical status. However, there is ample evidence from perception studies that rhythm plays a central role in language processing. To access word meaning, an incoming acoustic signal has to be segmented into smaller chunks which correspond to minimal meaningful units of speech. According to the rhythm-based segmentation account (Nazzi et al. 2006), segmentation strategies are dependent on the rhythmic type of a given language. Research in the area of language acquisition has shown that infants base the segmentation of their native language, as well as discrimination between languages, on the rhythmic class (Mehler et al. 1988, 1996, Bahrick and Pickens 1988, 
Jusczyk and Aslin 1995, Christophe and Morton 1998). Behavioural experiments demonstrate that also adults rely on the language's rhythmic type in cross-linguistic perception (Ramus and Mehler 1999). Moreover, a series of experimental studies on second language acquisition revealed that there is a significant correlation between the rhythmic class of a language and its intelligibility (Dupoux and Green 1997, Mehler et al. 1993, Pallier et al. 1998, Sebastián-Gallés et al. 2000). Specifically, this research shows that it is easier to understand a foreign language which belongs to the same rhythmic class as one's native language.

\section{The search for a phonological principle}

Phonetically-based approaches treat rhythm as an emergent phenomenon, arising from perceptual and articulatory factors. However, the fact that the subjective perception of rhythm has no direct phonetic correlates does not necessarily mean that it is not based on a phonological mechanism, which has prominent mental reality for both the speaker and the listener. In this respect, the concept of rhythm can be compared to the concept of other phonological concepts. For example, a phoneme, despite being used as one of the basic units of linguistic description, often does not have clearly defined acoustic, articulatory or perceptual correlates (Fox 2000: 91). Furthermore, even if rhythm is an emergent property, this does not mean that it does not follow its own principles.

It has been observed that rhythmic structure is created by stress patterns, and, conversely, that rhythm plays a role in phonological processes which govern the distribution of stressed syllables. For instance, the Rhythm Rule which operates in English and German shifts stress when another stressed syllable follows, $c f$. English fiftéen - fifteen péns, German ábnehmen 'take off' - den Hút abnéhmen 'take the hat off'. Bohn et al. (2013a) demonstrated in an EEG experiment that speakers of German are sensitive to violations of the Rhythm Rule: if exposed to violations of the preferred alternating pattern in phrases of the type just mentioned, they both detect the violation (as shown in a so-called N400 deflection) and evaluate this deviation (as shown in a subsequent positivity effect). Similar results were obtained by Henrich et al. (2014) for violations of the Rhythm Rule in English compounds. 
The intuition that stress is partly based on rhythm and may create rhythmically preferred structures has been at the foundation of the metrical theory of stress (Liberman 1975, Halle and Vergnaud 1987, Hayes 1981, 1995). This model breaks away with the tradition of representing stress as a segmental feature, on a par with nasality or voicing, but assumes that stress is a syntagmatic property of a speech sequence. In this conception, rhythm can be read off from a layered system of grid marks representing alternations of strong and weak elements; see in particular Prince (1983). As mentioned earlier, the abstract structuring of linguistic constituents does not have clear acoustic correlates. The phonological concept of rhythm should be distinguished from the surface timing patterns involving recurrence of salient points in utterances, which is usually explained without reference to phonology $^{5}$. For example, in a trochaic foot, there is opposition between a stressed and an unstressed syllable. Thus, the first line of the English popular nursery rhyme can be represented with grids as in (1a). A metrical grid shows sequences of equally spaced beats which alternate in prominence. Each syllable is assigned a grid mark in the first row, whereas only stressed syllables are represented in the second row. The grid structure formally depicts basic characteristics of rhythm, such as a hierarchical structure and a tendency to even spacing (Hayes 1995: 27). However, the theory of metrical grids was developed on the basis of stress-timed languages like English, and it is not clear at all how it can be employed to model the rhythmic pattern of syllable-timed and mora-timed languages. Nespor et al. (2011) note that, given that rhythmic beats correspond to each consecutive syllable or mora, there is no formal way to represent the strong/weak relationship of successive units. This is illustrated by the grid structures of two nursery rhymes, one from stress-timed English, the other one from an (allegedly) syllable-timed language, Polish.

${ }^{5}$ We would like to thank a reviewer for drawing this fact to our attention. 
(1) English vs. Polish grid structure

a. English

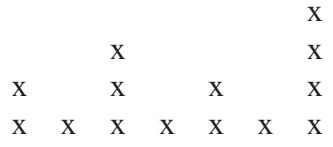

Jack and Jill went up the hill b. Polish

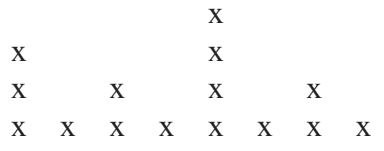

Była sobie żabka mała

"There was once a little frog"

It is evident that, besides indicating strong syllables, metrical grid structure tells us nothing about the Polish 'syllable-timing'. Yet, if "stress-timing in English reflects a fundamental and important aspect of the linguistic system, namely, the existence of what we have called the metrical grid" (Liberman 1975: 269), then it is plausible to assume that other types of rhythmic structures, though derived by different mechanisms, stem from the same principle.

It is standardly assumed that all prosodic units play an equally important role in all languages. In contrast to this view, one may assume that each language chooses one basic unit of processing which is fundamental for prosodic organization, and that the rhythmic class is determined by the choice of such a unit: a syllable in syllable-timed languages, a foot in stress-timed languages and a mora in mora-timed languages. Note that this assumption is in accordance with the results obtained in the studies on language acquisition (Nespor et al. 2011), which demonstrate that infants access the phonological system of the ambient language through its rhythmic type and use feet, syllables and moras as segmentation units in stress-timed, syllable-timed and mora-timed languages, respectively ${ }^{6}$.

Furthermore, since rhythmic units are the basic prosodic primes through which speech is accessed and processed, the level at which rhythm is defined can be assumed to be the central level of prosodic organization in a given language, in the sense that other prosodic units that can be potentially constructed above the 'rhythm tier' are either absent or play a subsidiary role in the prosodic structure. The implication of this view is that feet do not play

6 There appears to be some discrepancy between perception and production in the acquisition of rhythm. Allen and Hawkins (1980: 231) report that two-year old English children produce syllable-timed rhythm, even though the ambient language is stress-timed. 
a role in syllable-timed languages and syllables do not play a role in moratimed languages. In its strong version, this hypothesis might even entail that there are no feet in syllable-timed languages, and that there are no syllables in mora-timed languages. In other words, the existence of foot structure presupposes the existence of syllable structure, but not the other way round.

This assumption is backed up by experimental findings on stress perception demonstrating that feet play a role in the processing of word stress in German, but not in Turkish (Knaus et al. 2007, Domahs et al. 2008, Domahs et al. 2013). Specifically, the studies on metrical perception in German using electrophysiological measures have revealed distinct neural responses to stress shifts which either changed or preserved foot structure. These results dovetail with the fact that German is traditionally described as a stress-timed language, and Turkish as a syllable-timed language. It remains to be seen what the function of the syllable and the feet is in mora-timed and stresstimed languages. The assumption denying the existence of syllables in moratimed languages is particularly controversial because the concept of the syllable has played a central role in most phonological theorizing ${ }^{7}$. Moreover, the universality of the syllable has rarely been questioned (in contrast to the foot, which has not been recognized as a prosodic unit in syllable-timed languages such as French). But if the syllable is not an abstract entity in mora-timed languages, then these languages should not have syllable-related phonological processes. And, indeed, Labrune (2012) argues convincingly that the syllable does not play any role in the phonology of mora-timed Tokyo Japanese, and demonstrates that the mora is the basic prosodic unit, which is dominated directly by the foot in the prosodic hierarchy of Japanese.

\section{Conclusion and final remarks}

This article has discussed the notion of linguistic rhythm and the phonetic and phonological basis of the standardly assumed division into three different rhythmic types. On the one hand, phonetic measurements fail to provide a justification for a traditional division into rhythmic classes. On the other

7 It should be noted that the syllable has not been recognised as an autonomous unit in early generative phonology (Chomsky and Halle 1968), as well as in Government Phonology (Kaye, Lowenstamm and Vergnaud 1985), and in Beats-and-Binding Phonology (Dziubalska-Kołaczyk 2002). 
hand, phonological accounts often refer to the phenomenon of rhythm in relation to different prosodic phenomena, yet its formal role is not made explicit, and a coherent phonological theory of rhythm is still lacking. It has been suggested that rhythmic differences between languages can be best accounted for by means of language-specific phonological properties. We assumed that the existence of rhythmic types reflects structural differences in the prosodic organization of different languages. One obvious advantage of this approach over models claiming that rhythm is "an automatic consequence of linguistic circumstance" (Classe 1939: 132) is that it re-establishes the link between rhythm and stress. Most current studies on rhythmic structure relegate stress to a secondary position by assuming that it is just one of many factors affecting the subjective perception of rhythm (Dauer 1983, Auer 1993, Ramus at al. 1999, Grabe and Low 2002, Dellwo 2010). However, there are indications that the relation between rhythm and stress is much closer than has been supposed before. Fox (2000: 244) observes that only stress-timed rhythm is linked with stress, and that languages lacking word stress have syllable-timed rhythm. For instance, syllable-timed French is considered to have only a phrasal accent and no word stress as such. Interestingly, tonal languages which do not have stress also belong to this group (for example, Cantonese and Vietnamese). Counterevidence is provided by Spanish and Italian, which are often used as examples of syllable-timing. Stress in these languages has higher functional load than stress in classic stress-timed languages like English or German, and is frequently used to distinguish word meanings. It might be the case, then, that syllable-timing is a default, an unmarked pattern.

Additionally, the assumption that the percept of rhythm relies on stress allows us to draw interesting parallels between linguistic and non-linguistic rhythmic systems. Research in the area of neuroscience shows that accented events attract attention in different types of temporal activities (Drake et al. 2000). In music, for example, louder notes are perceived as more prominent. Experimental research (Grahn and Brett 2007, Potter et al. 2009) also reveals that humans detect rhythm in sequences in which there are no changes of volume. In the latter case, the perception of accents is based solely on the temporal organization. It is conceivable that, in linguistic systems, syllable-timing occurs when there are no clearly detectable accentual peaks. If this is the case, then the traditional division of languages into stress- and syllable-timed classes reflects a more general cognitive mechanism. Furthermore, Parncutt 
(1994) demonstrates that in a string of identical temporal events, the final unit is perceived as accented. So again one finds a parallel in linguistic systems: syllable-timed French has no word stress but a final phrase accent. Obviously, there is a possibility that French is an isolated case, which does not reflect any universal linguistic regularity.

\section{Bibliography}

Allen G. D., Hawkins S., 1980, Phonological rhythm: Definition and development, in: G. H. Yeni-Komshian, J. F. Kavanagh, C. A. Ferguson (eds.), Child phonology. Volume 1: Production, New York: Academic Press, p. 227-256.

Arvaniti A., 2009, Rhythm, Timing and the Timing of Rhythm, Phonetica 66, p. 46-63.

Auer P., 1993, Is a rhythm-based typology possible? A study of the role of prosody in phonological typology, KontRI Working Paper 21, Hamburg: Universität Hamburg.

Avanesov R. I., Orlova V. G. (eds.), 1965, Russkaja dialektologija, Moscow: Nauka.

Bahrick L. E., Pickens J. N., 1988, Classification of bimodal English and Spanish language passages by infants, Infant Behavior and Development 11, p. 277-96.

Bohn K., Knaus J., Wiese R., Domahs U., 2013a, The influence of rhythmic (ir)regularities on speech processing: evidence from an ERP study on German phrases, Neuropsychologia 51, p. 760-771.

Bolinger D., 1965, Pitch accent and sentence rhythm, Forms of English: Accent, morpheme, order, Cambridge, MA: Harvard University Press.

Chomsky N., Halle M., 1968, The Sound Pattern of English, New York: Harper and Row.

Christophe A., Morton J., 1998, Is Dutch native English? Linguistic analysis by 2-month-olds, Developmental Science 1 (2), p. 215-219.

Classe A., 1939, The Rhythm of English Prose, Oxford: Blackwell.

Crosswhite K., 2001, Vowel Reduction in Optimality Theory, New York: Routledge.

DASHER R., BOLInger D., 1982, On pre-accentual lengthening, Journal of the International Phonetic Association 12, p. 58-69.

DAuer R. M., 1983, Stress-timing and syllable-timing reanalysed, Journal of Phonetics 11, p. 51-62.

DAuER, R. M., 1987, Phonetic and phonological components of language rhythm. Proceedings of $11^{\text {th }} \mathrm{ICPhS}$, Tallinn, vol. 5, p. 447-450.

Dellwo V., 2010, Influences of speech rate on the acoustic correlates of speech rhythm: An experimental phonetic study based on acoustic and perceptual evidence, PhD-Dissertation, Universität Bonn. 
Domahs U., Genc S., Knaus J., Wiese R., Kabak B., 2013, Processing (un-) predictable word stress: ERP evidence from Turkish, Language and Cognitive Processes 28 , p. 335-354.

Domahs U., Wiese R., Bornkessel-Schlesewsky I. D., Schlesewsky M., 2008, The processing of German word stress: evidence for the prosodic hierarchy, Phono$\log y 25$, p. 1-36.

Drake C., Jones M. R., Baruch C., 2000, The development of rhythmic attending in auditory sequences: Attunement, referent period, focal attending, Cognition 77, p. 251-288.

Dupoux E., Green K., 1997, Perceptual adjustment to highly compressed speech: Effects of talker and rate changes, Journal of Experimental Psychology: Human Perception and Performance 23, p. 914-27.

Dziubalska-KoŁaczyк, K., 2002, Beats-and-Binding Phonology, Frankfurt: Peter Lang.

FARNetAni E., Kori S., 1990, Rhythmic structure in Italian noun phrases: A study on vowel durations, Phonetica 47, p. 50-65.

Fox A., 2000, Prosodic Features and Prosodic Structure: The Phonology of Suprasegmentals, Oxford: Oxford University Press.

Grabe E., Low E. L., 2002, Durational variability in speech and the rhythm class hypothesis, in: C. Gussenhoven, N. Warner (eds.) Papers in Laboratory Phonology 7, Berlin: Mouton de Gruyter, p. 515-546.

Grahn J.A., Brett M., 2007, Rhythm and Beat Perception in Motor Areas of the Brain, Journal of Cognitive Neuroscience 19, p. 893-906.

Halle M., Vergnaud J.-R., 1987, An Essay on Stress, Cambridge, Mass.: MIT Press.

HAYEs B., 1981, A metrical theory of stress, Bloomington: Indiana University Linguistic Club.

HAyes B., 1995, Metrical stress theory: principles and case studies, Chicago: Univ. of Chicago Press.

Henrich K., Alter K., Wiese R., Domahs U., 2014, The relevance of rhythmical alternation in language processing: an ERP study on English compounds, Brain and Language 136, p. 119-130.

Jassem W., Hill D. R., Witten I. H., 1984, Isochrony in English Speech: its Statistical Validity and Linguistic Relevance, in: D. Gibbon, H. Richter (eds.), Intonation, accent, and rhythm: studies in discourse phonology, Berlin: de Gruyter, p. 203-225.

Jusczyk P., W., Luce P. A., Charles-Luce J., 1994, Infants' sensitivity to phonotactic patterns in the native language, Journal of Memory and Language 33, p. 630-645.

Jusczyk P. W., Asuin R. N., 1995, Infants' detection of the sound patterns of words in fluent speech, Cognitive Psychology 29, 1-23.

KasatKin L. L., 2005, Russkaja dialektologija, Moscow: Akademia. 
Kaye J., J. Lowenstamm, Vergnaud J.-R., 1985, The Internal Structure of Phonological Elements: A Theory of Charm and Government, Phonology Yearbook 2, p. 305-321.

LABRUNE L., 2012, Questioning the universality of the syllable: evidence from Japanese, Phonology 29, p. 113-152.

LeHISTE I., 1977, Isochrony reconsidered, Journal of Phonetics 5, p. 253-263.

Lewis G. L., 1967, Turkish Grammar, Oxford: Clarendon Press.

LiBerman M., 1975, The intonational system of English, PhD dissertation, MIT.

Lloyd James A., 1940, Speech signals in telephony, London: Pitman and Sons.

Major R. C., 1981, Stress-timing in Brazilian Portuguese, Journal of Phonetics 9, p. 343-351.

Malisz Z., 2011, Tempo differentiated analyses of timing in Polish. Proceedings of the XVII International Congress of Phonetic Sciences, Hong Kong, p. 1322-1325.

Mehler J., Dupoux E., Nazzi T., Dehaene-Lambertz G., 1996, Coping with linguistic diversity: the infant's viewpoint, in: J. L. Morgan, K. Demuth (eds.), Signal to Syntax: Bootstrapping from Speech to Grammar in Early Acquisition, Mahwah, NJ: Lawrence Erlbaum Associates.

Mehler J., Jusczyk P. W., Lambertz G., Halsted G., Bertoncini J., Amiel-Tison C., 1988, A precursor of language acquisition in young infants, Cognition 29, p. 143-78.

Mehler J., Sebastián-Gallés N., Altmann G., Dupoux E., Christophe A., Pallier P., 1993, Understanding Compressed Sentences: The Role of Rhythm and Meaning, New York: Annals of the New York Academy of Sciences.

Nazzi, T., Iakimova, G., Bertoncini, J., Fredonie, S., Alcantara, C., 2006, Early segmentation of fluent speech by infants acquiring French: Emerging evidence for crosslinguistic differences, Journal of Memory and Language 54 (3), p. 283-299.

Nespor M., Shukla M., Mehler J., 2011, Stress-timed vs. syllable-timed languages, in: M. van Oostendorp, C. J. Ewen, E. Hume, K. Rice (eds.), The Blackwell Companion to Phonology, London: Blackwell Publishing.

O’Connor J. D., 1980, Better English Pronunciatio, $2^{\text {nd }}$ edition, Cambridge: Cambridge University Press.

Pallier C., Sebastián-Gallés N., Dupoux E., Christophe A., Mehler J., 1998, Perceptual adjustment to time-compressed speech: A cross-linguistic study, Memory and Cognition 26, p. 844-51.

PARncutt R., 1994, A perceptual model of pulse salience and metrical accent in musical rhythms, Music Perception 11, p. 409-464.

Payne E., Post, B., Astruc L., Prieto, P., Vanrell, M., 2012, Measuring child rhythm, Language and Speech 55(2), p. 202-228.

PIKE K. L., 1945, The intonation of American English, Ann Arbor, MI: University of Michigan Press. 
Potter D. D., Fenwick M., Abecasis D., Brochard R., 2009, Perceiving rhythm where none exists: Event-related potential (ERP) correlates of subjective accenting, Cortex 45, p. 103-105.

Prieto P., Vanrell M. M., Astruc L., Payne E., Post B., 2012, Phonotactic and phrasal properties of speech rhythm. Evidence from Catalan, English, and Spanish, Speech Communication 54, p. 681-702.

Prince A. S., 1983, Relating to the grid. Linguistic Inquiry 14, p. 19-100.

Ramus F., Mehler J., 1999, Language identification with suprasegmental cues: A study based on speech resynthesis, Journal of the acoustical society of America 105, p. 512-521.

Ramus F., Nespor M., Mehler J., 1999, Correlates of linguistic rhythm in the speech signal, Cognition 73, p. 265-292.

Ramus, F., Dupoux, E., Mehler, J., 2003, The psychological reality of rhythm classes: Perceptual studies. Proceedings of the 15th International Congress of Phonetics Sciences, Barcelona, p. 337-342.

Sebastián-Gallés N., Dupoux E., Costa A., Mehler J., 2000, Adaptation to time-compressed speech: Phonological determinants, Perception and Psychophysics 62, p. $834-842$.

Sjoberg A. F., 1963, Uzbek Structural Grammar, Bloomington: Indiana University Press.

Sweet H., 1906, A Primer of Phonetics, Oxford: Clarendon Press.

\section{Rytm tkwi w umyśle. Uwagi na temat rytmu w języku}

(streszczenie)

Celem artykułu jest omówienie współczesnych teorii rytmu występującego w językach naturalnych. Na poziomie percepcji języki można podzielić na trzy typy rytmiczne oparte na przycisku, sylabie i morze. W językach z rytmem opartym na przycisku, sylaby akcentowane pojawiają się w regularnych przedziałach czasowych, podczas gdy w językach z rytmem sylabicznym i morowym, sylaby i mory występują w równych odstępach czasu. Mimo że liczne badania fonetyczne nie potwierdziły istnienia izochronizmu w potoku mowy, istnieje wiele dowodów wskazujących na to, iż rytm odgrywa istotną rolę w przetwarzaniu języka. W niniejszym artykule dostarczamy argumentów na to, że modele fonetyczne traktujące rytm jako zjawisko podrzędne nie są wystarczające dla opisu różnych systemów językowych oraz wskazujemy, że intuicyjne pojęcie rytmu powinno być włączone do analizy fonologicznej. 